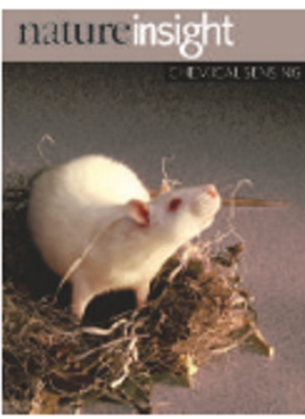

Cover illustration

For many animals, such as the ratpicturedhere, smell and taste are crucial for sensing their enviranment.

Editor, Nature Philip Campbell Insights Publisher Sarah Greaves Insights Editor Lesley Anson

Production Editor Sarah Archibald

Senior Art Editor Martin Harrison

Art Editor

Nik Spencer

Sponsorship

Claire Hines

Claudia Banks

Production

Susan Gray

Marketing

Katy Dunningham

EditorialAssistant LauraShaw

\title{
CHEMICAL SENSING
}

1 aste and smell contribute critically to our experience of our environment, from the pleasure of eating to the formation of childhood memories. Despite this, research into chemical sensing historically took a back seat to vision and audition, challenged by the complexities of indefinable stimuli that are often not even consciously processed, and by difficulties in uncovering even the basic mechanisms of transduction and representation.

Then, in 1991, Buck and Axel identified the genes for odorant receptors, launching chemical-sensing research to the forefront. The reviews in this Insight highlight the progress made during the past fifteen years, and emphasize how the stage is set to tackle fundamental questions about the brain and behaviour.

New experimental tools, such as sophisticated methods for labelling, recording and manipulating neuronal activity and projections, have provided researchers with insight into the principles by which the taste and olfactory systems decode and represent environmental stimuli. An important goal that now seems attainable is to understand how this processing translates into, in some instances, innate behaviours and, in others, learned behaviours.

The findings reviewed here are not only remarkable intellectual achievements, but are also of great potential value to society. Understanding the cues and mechanisms through which humans and other animals are attracted to or repulsed by chemosensory stimuli holds promise for tackling several major problems facing modern human society - from the control of disease-bearing insects to causes of overeating.

We are pleased to acknowledge the financial support of our principal sponsor Givaudan and our supporting sponsors ChemCom and the National Institute on Deafness and Other Communication Disorders in producing this Insight. As always, Nature carries sole responsibility for all editorial content and peer review.

I-han Chou, Tanguy Chouard, John E. Spiro \& Lesley Anson, Senior Editors

\section{REVIEWS}

288 The receptors and cells for mammalian taste

J. Chandrashekar, M. A. Hoon, N. J. P. Ryba \& C. S. Zuker

295 Comparative chemosensation from receptors to ecology
C. I. Bargmann

302 Insects as chemosensors of humans and crops

W. van der Goes van Naters \& J.R. Carlson

308 Pheromonal communication in vertebrates

P. A. Brennan \& F. Zufall

316 Smell images and the flavour system in the human brain

G. M. Shepherd

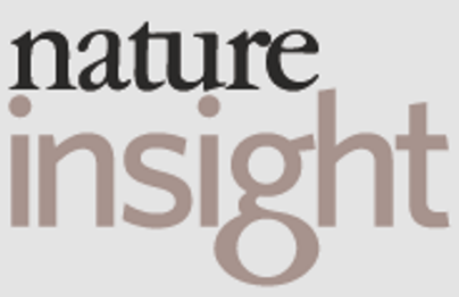

